\title{
A Research on Nonperforming Assets of Banks in India
}

\section{R.S.N.Sharma}

\begin{abstract}
Accepting deposits and lending loans is the primary function of banks. They lend loans on certain terms and conditions. Some of the granted loans may be continuously, periodically and systematically repaid by the borrowers as per the agreed terms and conditions but may not be repaid in time and there may be time lag in repayment. Sometimes the time lag may become longer and irrecoverable. The loan granted by the bank is asset to the bank as it is receivable amount to bank. If the loan is being systematically repaid by the borrower, it is performing asset, otherwise if it is not being paid regularly and properly it is said to be non performing asset. If payments of interest and/ or principal are in default for more than 90 days period, generally it is considered as non-performing asset. Nonperforming assets are burden to banks. They adversely affect the performance of banks and sometimes increasing non-performing assets may lead to closure of business also. These should be regularly reviewed, monitored, analysed and ultimately controlled for the smooth running of bank. For this a systematic regulatory mechanism must be employed and ensured its perfect execution. In this paper an attempt has been made to make study on Non-Performing assets of banks in various sectors in India by using percentages, Indexed values. The study is completely based on secondary data collected from handbook of statistics of Reserve Bank of India. The collected data is tabulated, analysed and conclusions are drawn.
\end{abstract}

Terminology: Non-Performing Asset, Performing-Asset, Indexed values

\section{INTRODUCTION}

Accepting deposits and lending loans is the primary function of banks. They lend loans on certain terms and conditions. Some of the granted loans may be continuously, periodically and systematically repaid by the borrowers as per the agreed terms and conditions but may not be repaid in time and there may be time lag in repayment. Sometimes the time lag may become longer and irrecoverable. The loan granted by the bank is asset to the bank as it is receivable amount to bank. If the loan is being systematically repaid by the borrower, it is performing asset, otherwise if it is not being paid regularly and properly it is said to be Nonperforming Asset. If payments of interest and/ or principal are in default for more than 90 days period, generally it is considered as non-performing asset. According International Monitory Fund (IMF), a loan becomes as Non-Performing Asset when:

- If the loan is in default for 90 days period ( Principal and/or interest)

- Interest payments at least for 90 days period are delayed or capitalised
- The past 90 days due in default is still accruing interest.

- The loans which are considered as non-accrual.

The nonaccrual loans are common in agriculture sector in India where formers may not be able to clear their dues due to losses that arise to them as the climatic conditions are not in their favour.

Non-performing Assets are burden to banks. They adversely affect the performance of banks and sometimes increasing non-performing assets may lead to closure of business also. These should be regularly reviewed, monitored, analysed and ultimately controlled for the smooth running of bank. For this a systematic regulatory mechanism must be employed and ensured its perfect execution.

In 2014, CRILC (Central Repository of Information on Large Credits) and in 2015, AQR (Asset Quality Review) were set up by Reserve Bank of India for recognition and asset quality review. By this it is possible to recognise the following facts. Gross NPA ratio in 2015-March, $4.3 \%$ this raised to $7.5 \%$ in 2016 March and reached the peak, $11.5 \%$ in 2018. Reserve Bank of India has been making various efforts in strengthening its regulatory and supervisory framework and resolution mechanism instituted through Insolvency and Bankruptcy code (IBC). These steps are improving the situations. Significant decline in gross Nonperforming assets ratio is evident for that. During the year end 2017-18 gross non-performing asset ratio of Scheduled Commercial Banks was $11.5 \%$. It has declined to $9.3 \%$ on $31^{\text {st }}$ March 2019. Provision coverage ratio of the same has been improved from $48.3 \%$ (March-2018) to $60.9 \%$ (March-2019). (Governor, Shaktikanta Das said at NIBM, Pune-Business Line $9^{\text {th }}$ June, 2019).

\section{REVIEW OF LITERATURE}

- $\quad$ Vivekrajbahadur Singh (2016): “A study on NPAs of commercial banks and its recovery in India" Annual Research Journal of SCMS, Pune-Vol-4: March-2016.

Researcher analysed and concluded that NPAs in Public sector banks are higher. Problem is highly with large borrowers. Necessary steps are to be taken to curb the situation.

- $\quad$ Dr Rajkumar Mittal \& Ms Deeksha Suneja (2017): " The problem of rising NPAs in Banking sector in IndiaComparative Analysis of public and private sector banks "International Journal of Management IT and Engineering ISSN 2249-0558

Revised Manuscript Received on September 10, 2019.

Dr R.S.N.Sharma, M.Com. M.Phil., MBA. B.Ed., AP.SET., Ph.D Associate Professor, Head of the Department of Commerce, Ch.S.D.St Theresa's Degree College for women, Eluru (AP), India.

(E-mail: ryalisivanag@gmail.com) 
IF-7.119. the researchers have made an attempt to find and conclude that when compared to private sector banks, public sector banks are having higher quantum of Nonperforming Assets. Government is to take concrete steps to curb the situation.

Significant decline in gross Nonperforming assets ratio is evident for that.

- $\quad$ Suvitha K Vikram \& Gayathri G (2018) : “A study on NPAs in Indian banking sector" International Journal of Pure and Applied Mathematics-Volume-118, No.20

2018- ISSN 1314-3395. Researchers through their study opined that Majority of the articles reported that public sector banks are having higher NPAs and these reveal the level and controlling measures of NPAs

\section{OBJECTIVES OF THE STUDY}

- To study the concept of Non-performing Assets in Indian Banking Sector

- To evaluate the Non-performing Assets of banks in various sectors

- To find out the reasons for Non-Performing Assets

- To provide suggestions to control the NonPerforming Assets

\section{METHODOLOGY}

The total study depends on secondary data collected from various annual reports and Hand book of Statistics of Reserve bank of India. The collected information was tabulated, analysed depicted in charts and conclusions drawn.

\section{TOOLS USED}

To analyse the collected information, percentages and indexed values are used accordingly results and conclusions are drawn.

\section{LIMITATIONS OF THE STUDY}

The analysed information was collected from 2005-06 to 2016-17 for the period of 12 years and the data in case of Old Private banks was available from2005-06 to2012-13. The facts after the above specified periods may change the present study and analysis.

\section{PERIOD OF STUDY}

The study period was 12 years starting from 2005-06 to 2016-17 for the banks in all the specified sectors except in the case of Old Private Banks for which it was 8 years from 2005-06 to 2012-13 as the information was available for that period only.

\section{STATEMENT OF PROBLEM}

Increasing Non-Performing Assets of banks in various sectors of India and analysing the facts and figures to find better solutions to control the unfavourable situations to banks that arise due to Non-Performing Assets.

\section{DATA SOURCES}

The study completely depends on secondary data collected from annual reports and Hand Book of Statistics of Reserve Bank of India and other sources.

\section{DATA ANALYSIS \& RESULTS}

The total study is based on secondary data collected from annual reports and Handbook of statistics on Indian economy of Reserve Bank of India website. The collected information was serially arranged, tabulated, analysed with the help of percentages and indexed values, depicted in diagrams and finally findings and conclusion were drawn.

(1)NPAs of Scheduled Commercial Banks Rs. (billion)

\begin{tabular}{|l|l|l|l|l|l|}
\hline Year & $\begin{array}{l}\text { NPAs } \\
\text { in Rs }\end{array}$ & $\begin{array}{l}\% \text { of } \\
\text { NPAs in } \\
\text { advances }\end{array}$ & $\begin{array}{l}\text { Increase } \\
\text { in } \\
\text { NPAs }\end{array}$ & $\begin{array}{l}\text { Index } \\
\% \text { in } \\
\text { Total } \\
\text { Assets }\end{array}$ \\
\hline $\begin{array}{l}2005- \\
06\end{array}$ & 185.43 & 1.2 & --- & 100.00 & 0.7 \\
\hline $\begin{array}{l}2006- \\
07\end{array}$ & 202.80 & 1.0 & 9.37 & 109.37 & 0.6 \\
\hline $\begin{array}{l}2007- \\
08\end{array}$ & 247.30 & 1.0 & 21.94 & 133.37 & 0.6 \\
\hline $\begin{array}{l}2008- \\
09\end{array}$ & 315.64 & 1.1 & 27.63 & 170.22 & 0.6 \\
\hline $\begin{array}{l}2009- \\
10\end{array}$ & 391.27 & 1.1 & 23.96 & 211.01 & 0.6 \\
\hline $\begin{array}{l}2010- \\
11\end{array}$ & 417.99 & 1.0 & 6.83 & 225.42 & 0.6 \\
\hline $\begin{array}{l}2011- \\
12\end{array}$ & 652.05 & 1.3 & 56.00 & 351.64 & 0.8 \\
\hline $\begin{array}{l}2012- \\
13\end{array}$ & 986.93 & 1.7 & 51.36 & 532.24 & 1.0 \\
\hline $\begin{array}{l}2013- \\
14\end{array}$ & 1426.56 & 2.1 & 44.55 & 769.33 & 1.3 \\
\hline $\begin{array}{l}2014- \\
15\end{array}$ & 1758.41 & 2.4 & 23.26 & 948.29 & 1.5 \\
\hline $\begin{array}{l}2015- \\
16\end{array}$ & 3498.14 & 4.4 & 98.94 & 1886.50 & 2.7 \\
\hline $\begin{array}{l}2016- \\
17\end{array}$ & 4330.10 & 5.3 & 23.78 & 2335.17 & 3.1 \\
\hline
\end{tabular}

Source: RBI Hand book of statistics

(1A) NPAs of Scheduled Commercial Banks Rs. (billion)

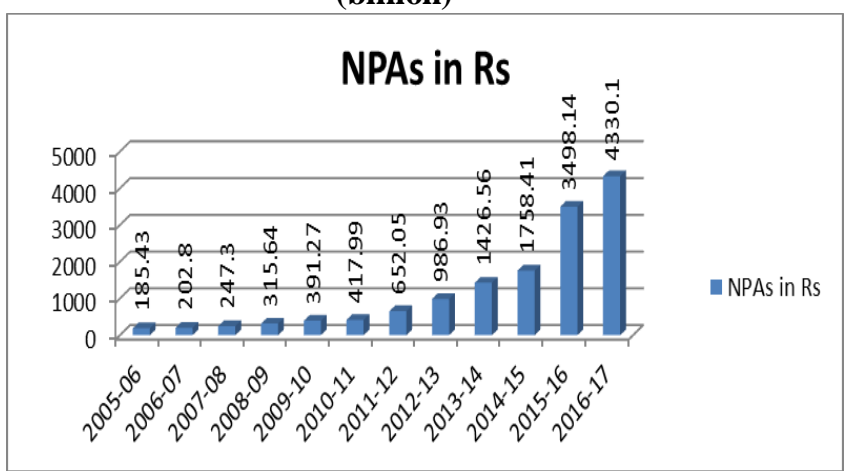

Source: RBI Hand book of statistics 


\section{Analysis \& Interpretation}

Growth\% is calculated by taking increased value in the following year basing

On the previous value in per cent. All growth rates are increased percentage rates over

that of previous years Index value is considered as that year value as a percentage

over the value of first year of the study period. During the study period overall index

II Values are in increasing trend

The above table 1 and diagrammatic illustration 1(A) show that NPAs of Scheduled Commercial Banks have been increasing since 2005-06. \% of increase is highest in

2015-16(98.94\%) and lowest in 2010-11 (6.83\%).During the study period in the years

2007-08 to 2009-10 and in 2014-15; 2015-16 it is ranging between 21.94 and 27.63;

2011-12 to $2013-14$ it is in between $44.55 \%$ to $56 \%$. Index values are continuously in increasing trend and highest increase has been registered in the last two years 2015-16 (1886.50) and 2016-17 (2335.17) of the study period, \% of npa in net advances are least in the years 200607 and 2007-08 (1.0\%) and highest in the year 2016-17 (5.3). NPAs \% in Total Assets is least $(.6 \%)$ in the years 2009-07 to 2010-11 and highest (3.1\%) in the year 2016-17

(2) NPAs of Public Sector Banks Rs. (billion)

\begin{tabular}{|l|l|l|l|l|l|}
\hline Year & $\begin{array}{l}\text { NPAs } \\
\text { in Rs }\end{array}$ & $\begin{array}{l}\text { \% of npa } \\
\text { in net } \\
\text { advances }\end{array}$ & $\begin{array}{l}\text { \% of } \\
\text { Increase } \\
\text { NPAs }\end{array}$ & Index & $\begin{array}{l}\text { NPAs } \\
\% \text { in } \\
\text { Total } \\
\text { Assets }\end{array}$ \\
\hline $\begin{array}{l}2005- \\
06\end{array}$ & 145.66 & 1.3 & --- & 100.00 & 0.7 \\
\hline $\begin{array}{l}2006- \\
07\end{array}$ & 153.25 & 1.1 & 5.21 & 105.21 & 0.6 \\
\hline $\begin{array}{l}2007- \\
08\end{array}$ & 178.36 & 1.0 & 16.38 & 122.45 & 0.6 \\
\hline $\begin{array}{l}2008- \\
09\end{array}$ & 211.55 & 0.9 & 18.61 & 145.24 & 0.6 \\
\hline $\begin{array}{l}2009- \\
10\end{array}$ & 296.43 & 1.1 & 40.12 & 203.51 & 0.7 \\
\hline $\begin{array}{l}2010- \\
11\end{array}$ & 360.55 & 1.1 & 21.63 & 247.53 & 0.7 \\
\hline $\begin{array}{l}2011- \\
12\end{array}$ & 593.91 & 1.5 & 64.72 & 407.74 & 1.0 \\
\hline $\begin{array}{l}2012- \\
13\end{array}$ & 900.37 & 2.0 & 51.60 & 618.13 & 1.3 \\
\hline $\begin{array}{l}2013- \\
14\end{array}$ & 1306.35 & 2.6 & 45.09 & 896.85 & 1.6 \\
\hline $\begin{array}{l}2014- \\
15\end{array}$ & 1599.51 & 2.9 & 22.44 & 1098.11 & 1.8 \\
\hline $\begin{array}{l}2015- \\
16\end{array}$ & 3203.76 & 5.7 & 100.30 & 2199.48 & 3.5 \\
\hline $\begin{array}{l}2016- \\
17\end{array}$ & 3830.89 & 6.9 & 19.57 & 2630.02 & 3.9 \\
\hline Source. & 1.981 & & & \\
\hline
\end{tabular}

Source: RBI Hand book of statistics
(2A)NPAs of Public Sector Banks Rs. (billion)

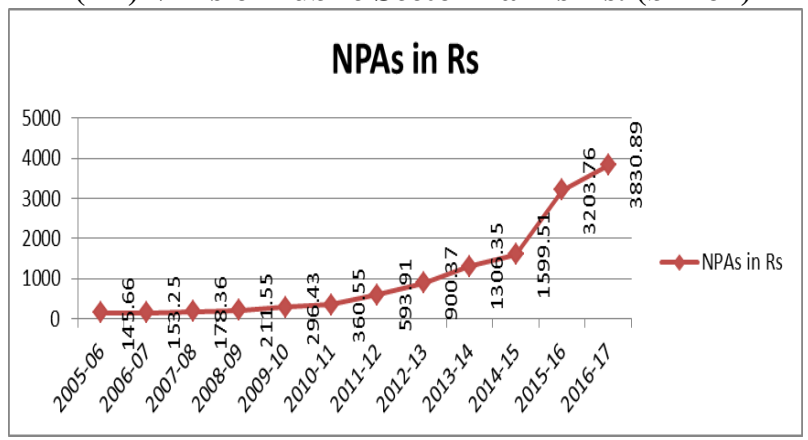

Source: RBI Hand book of statistics

Analysis \& Interpretation

The above table 2 and diagrammatic illustration $\mathbf{2 ( A )}$ show that NPAs of

Public Sector Banks have been increasing since 2005-06. $\%$ of increase is highest in

2015-16(100.30\%) and lowest in 2006-07 (5.21\%).During the study period in the years

2007-08 and 2008-09 and in 2010-11, 2014-15; 2016-17 it is ranging between 16.38 and $22.44 ; 2009-10$ to $2010-11$ to $2012-13$ it is in between $40.12 \%$ to $64.72 \%$. Index values are continuously in increasing trend and highest increase has been registered in the last two years 2015-16 (2199.48\%) and 2016-17 (2630.02\%) of the study period, \% of NPAs in net advances is least in the year 2008-09 (0.9\%) and highest in the year 2016-17 (6.9\%). NPAs \% in Total Assets is least $(0.6 \%)$ in the years $2006-07$ to $2008-09$ and highest (3.9\%) in the year 2016-17.

(3) NPAs of old private Sector Banks Rs. (billion)

\begin{tabular}{|l|l|l|l|l|l|}
\hline Year & $\begin{array}{l}\text { NPAs } \\
\text { in Rs }\end{array}$ & $\begin{array}{l}\text { NPAs in } \\
\text { advances }\end{array}$ & $\begin{array}{l}\% \text { of } \\
\text { increase } \\
\text { in } \\
\text { NPAs }\end{array}$ & Index & $\begin{array}{l}\text { NPAs } \\
\% \text { in } \\
\text { Total } \\
\text { Assets }\end{array}$ \\
\hline $\begin{array}{l}2005- \\
06\end{array}$ & 13.75 & 1.7 & -- & 100.00 & 0.9 \\
\hline $\begin{array}{l}2006- \\
07\end{array}$ & 8.91 & 1.0 & -35.20 & 64.80 & 0.6 \\
\hline $\begin{array}{l}2007- \\
08\end{array}$ & 7.40 & 0.7 & -16.95 & 53.82 & 0.4 \\
\hline $\begin{array}{l}2008- \\
09\end{array}$ & 11.59 & 0.9 & 56.62 & 84.29 & 0.5 \\
\hline $\begin{array}{l}2009- \\
10\end{array}$ & 12.71 & 0.8 & 9.66 & 92.44 & 0.5 \\
\hline $\begin{array}{l}2010- \\
11\end{array}$ & 9.00 & 0.5 & -29.19 & 65.45 & 0.3 \\
\hline $\begin{array}{l}2011- \\
12\end{array}$ & 13.00 & 0.6 & 44.44 & 94.55 & 0.3 \\
\hline $\begin{array}{l}2012- \\
13\end{array}$ & 20.00 & 0.7 & 53.85 & 145.45 & 0.4 \\
\hline
\end{tabular}

Source: RBI Hand book of statistics 
(3) NPAs of old private Sector Banks Rs. (billion)

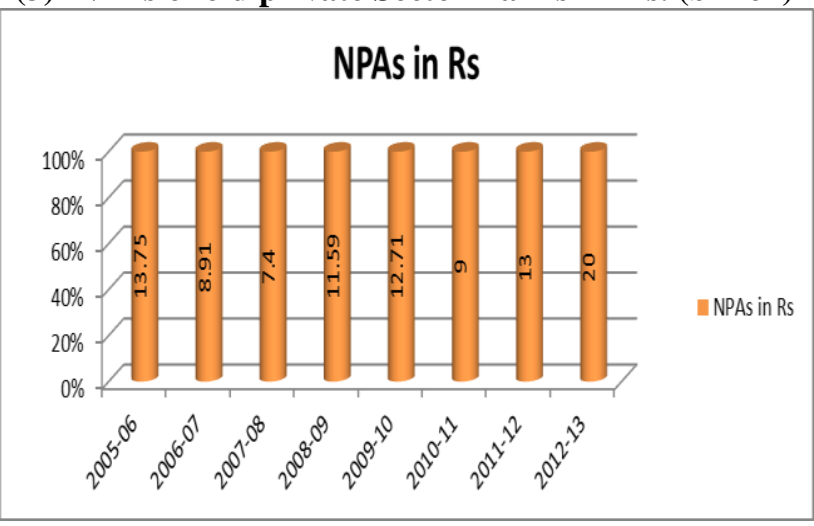

\section{Source: RBI Hand book of statistics}

Analysis \& Interpretation

The above table 3 and diagrammatic illustration $\mathbf{3 ( A )}$ show that NPAs of

Private Sector Banks are least in the year 2007-08 (7.4 billion) highest in 2012-13 (20.0billion). In the other years of study period it is ranging in between 8.91 billion and 13.75 billion. \% of NPAs in net advances, $0.5 \%$ is the lowest in the year $2010-11 ; 1.70 \%$ is the highest in 2005-06. In the other years of remaining study period, it is ranging in between $0.60 \%$ to $1.0 \%$. Regarding \% of Increase in NPAs, highest decreased (negative) percentage in the year 2006-07 $(-35.20 \%)$ and highest increased percentage in the year 2008-09 (56.62\%). In the years 2007-08 and 2010-11 they negative percentages $-16.95 \%$ and $29.19 \%$ which means in these years, NPAs are in decreasing trend at a decreased rate. Index values are in decreasing trend at a decreased rate continuously during the study period starting from

2005-06 to $2007-08,100 \% ; 64.80 \% 53.82 \%$. Since then except in the year $2010-11(65.45 \%)$, it is in the increasing trend from $84.29 \%$ to $145.45 \%$. \% of Total Assets, least in the years 2010-11 and 2011-12, 0.3\% and highest in 2005$06,0.9 \%$.

(4) New Private Sector Banks Rs.(billion)

\begin{tabular}{|c|c|c|c|c|c|}
\hline Year & $\begin{array}{l}\text { NPAs } \\
\text { in Rs }\end{array}$ & $\begin{array}{l}\text { \% of npa } \\
\text { in net } \\
\text { advances }\end{array}$ & $\%$ Increase & Index & $\begin{array}{l}\% \text { of } \\
\text { Total } \\
\text { Assets }\end{array}$ \\
\hline $\begin{array}{c}2005- \\
06\end{array}$ & 31.70 & 1.0 & --- & 100.00 & 0.6 \\
\hline $\begin{array}{c}2006- \\
07\end{array}$ & 40.28 & 1.0 & 27.07 & 127.07 & 0.5 \\
\hline $\begin{array}{c}2007- \\
08\end{array}$ & 56.47 & 1.1 & 40.19 & 178.14 & 0.6 \\
\hline $\begin{array}{c}2008- \\
09\end{array}$ & 74.12 & 1.3 & 31.26 & 233.82 & 0.7 \\
\hline $\begin{array}{c}2009- \\
10 \\
\end{array}$ & 65.06 & 1.0 & -12.22 & 205.24 & 0.6 \\
\hline $\begin{array}{c}2010- \\
11\end{array}$ & 44.32 & 0.6 & -31.88 & 139.81 & 0.3 \\
\hline $\begin{array}{c}2011- \\
12\end{array}$ & 44.01 & 0.5 & -0.70 & 138.83 & 0.3 \\
\hline $\begin{array}{c}2012- \\
13\end{array}$ & 59.94 & 0.5 & 36.20 & 189.09 & 0.3 \\
\hline $\begin{array}{c}2013- \\
14\end{array}$ & 88.62 & 0.7 & 47.85 & 279.56 & 0.4 \\
\hline $\begin{array}{c}2014- \\
15\end{array}$ & 141.28 & 0.9 & 59.42 & 445.68 & 0.5 \\
\hline $\begin{array}{c}2015- \\
16\end{array}$ & 266.77 & 1.4 & 88.82 & 841.55 & 0.8 \\
\hline $\begin{array}{c}2016- \\
17\end{array}$ & 477.80 & 2.2 & 79.11 & 1507.26 & 1.3 \\
\hline
\end{tabular}

Source: RBI Hand book of statistics
(4A) New Private Sector Banks Rs. (billion)

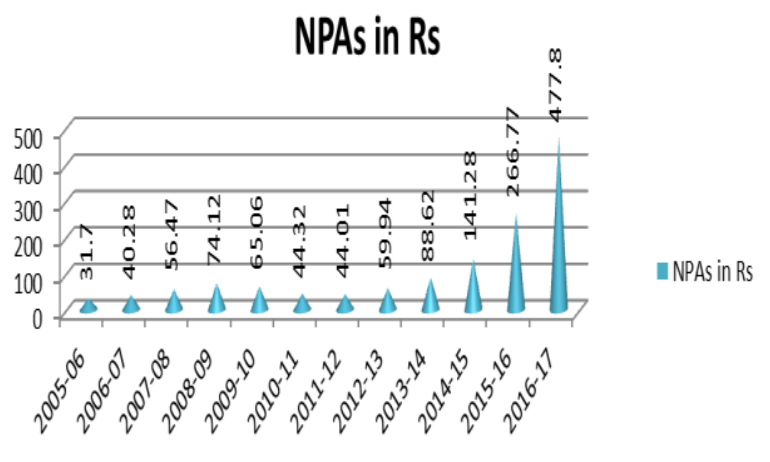

Source: RBI Hand book of statistics

(5) Foreign Banks in India Rs. (billion)

\begin{tabular}{|c|c|c|c|c|c|}
\hline Year & $\begin{array}{l}\text { NPAs } \\
\text { in Rs }\end{array}$ & $\begin{array}{l}\% \text { of npa } \\
\text { in net } \\
\text { advances }\end{array}$ & \%Increase & Index & $\begin{array}{l}\text { NPAs } \\
\% \text { in } \\
\text { Total } \\
\text { Assets }\end{array}$ \\
\hline $\begin{array}{c}2005- \\
06\end{array}$ & 8.08 & 0.8 & --- & 100.00 & 0.4 \\
\hline $\begin{array}{c}2006- \\
07\end{array}$ & 9.27 & 0.7 & 14.73 & 114.73 & 0.3 \\
\hline $\begin{array}{c}2007- \\
08\end{array}$ & 12.47 & 0.8 & 34.52 & 154.33 & 0.3 \\
\hline $\begin{array}{c}2008- \\
09\end{array}$ & 29.96 & 1.8 & 140.26 & 370.79 & 0.7 \\
\hline $\begin{array}{c}2009- \\
10\end{array}$ & 29.77 & 1.8 & -0.63 & 368.44 & 0.7 \\
\hline $\begin{array}{c}2010- \\
11\end{array}$ & 13.13 & 0.7 & -55.90 & 162.50 & 0.3 \\
\hline $\begin{array}{c}2011- \\
12\end{array}$ & 14.12 & 0.6 & 7.54 & 174.75 & 0.2 \\
\hline $\begin{array}{c}2012- \\
13\end{array}$ & 26.63 & 1.0 & 88.60 & 329.58 & 0.4 \\
\hline $\begin{array}{c}2013- \\
14\end{array}$ & 31.60 & 1.1 & 18.66 & 391.09 & 0.4 \\
\hline $\begin{array}{c}2014- \\
15\end{array}$ & 17.62 & 0.5 & -44.24 & 218.07 & 0.2 \\
\hline $\begin{array}{c}2015- \\
16\end{array}$ & 27.67 & 0.8 & 57.04 & 342.45 & 0.3 \\
\hline $\begin{array}{c}2016- \\
17\end{array}$ & 21.41 & 0.6 & -22.62 & 264.98 & 0.3 \\
\hline
\end{tabular}

Source: RBI Handbook of Statistics

(5A) Foreign Banks in India Rs. (billion)

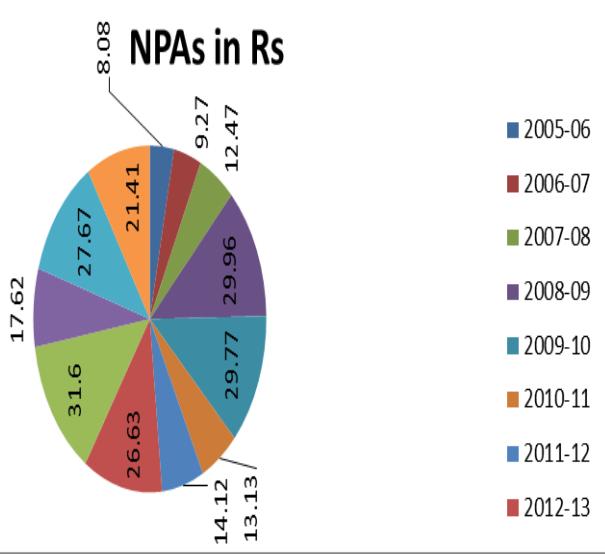

Source: RBI Hand book of statistics

Published By: 


\section{Analysis \& Interpretation}

The above table 5 and diagrammatic illustration 5(A) show that NPAs of Foreign Banks in India were increasing from 2005-06 to 2009-10 and decreased in 2010-11 and from the next year 2011-12, again started increasing till 2013-14 and later again there was a decreasing trend from 2013-14 till the last year of the study period 2016-17. On an average it is appearing to be in rising trend. \% of npa in net advances is highest in 2008-2009 and 2009-10(1.8\%) and lowest in 2014-15 (0.5\%).During the study period in the years $2005-06$ to $2007-08$ and $2010-11$ to $2015-16$, it is ranging between $0.5 \%$ to $1.1 \%$. \% of increase over the previous year, is highest in the year 2009-10 (140.26\%) and lowest in the year 2010-11

$(-55.90 \%)$ This is negative ( decreased) in the years, $2009-10(-0.63 \%)$ 2010-11

$(-55.90 \%) ; 2014-15(-44.24 \%)$ and $2016-17(-44.24 \%)$. During the years $2012-13(88.60 \%)$ and $2015-16(57.04 \%)$ the increased rates are higher. In the remaining years of study period they are ranging in between $14.73 \%$ ( 2006-07) $34.52 \%$ (2007-08). Index values though appearing to be decreased in the years2010-11 and 2011-12 on the whole they are in increasing trend.NPAs $\%$ in total assets is least $0.2 \%(2011-12 \& 2014-15)$ and highest $0.7 \%$ (2008$09 \& 2009-10)$ and in the remaining years of study period it is ranging between $0.3 \%$ and $0.4 \%$.

\section{Reasons for Non-Performing Assets and their increase}

Reasons for Non-Performing Assets are many. Some are not in control of banks and some can be controlled with systematic approach.

\section{Reasons that are not under the control of banks}

- Changes in government policies ; Changes in economic conditions

- Climatic conditions ; Natural calamities

(Particularly in case of Agriculture)

- Liberalisation policy

; Technical and industry related problems

- Changes in governments and interference of political leaders etc.

\section{Reasons that are under the control of banks}

- Improper project proposals ineffective scrutiny of these projects

- Internal management system and less professional expertise

- Over estimation and expectation about the products to be launched by the proposed project holders

- Non observance of procedures from the side of internal Management of Banks

- Non insistence of collaterals sanction monitoring

- Inadequate appraisal standards ; Insufficient post sanction etc.

\section{FINDINGS}

* During the period of study Nonperforming assets of Scheduled commercial banks in billions of rupees have been increasing at an increased rate. It has increased 23.35 times when compared to the figures of first year of study period.
Highest increased rate over the previous year rate $98.94 \%$ and lowest $6.83 \%$ have been registered in the years $2015-16$ and 2010-11.

* Nonperforming assets of Public Sector banks in billions of rupees have been increasing at an increased rate. It has increased 26.30 times when compared to the figures of first year of study period. Highest increased rate over the previous year rate $100.30 \%$ and lowest $5.21 \%$ have been registered in the years 2015-16 and 2006-07.

* Nonperforming assets of old private Sector banks in billions of rupees have been decreasing and increasing during the study period of 2005-06 to 2012-13.It has increased 1.5 times when compared to the figures of first year of study period. Highest increased rate over the previous year rate $56.62 \%$ and lowest- $35.20 \%$ ( decreased) have been registered in the years 2008-09 and 2006-07.

* Non-Performing Assets of new private Sector banks in billions of rupees though appearing to be decreased in the years 2009-10 to 2011-12, they have been increasing at an increased rate. It has increased 15.07 times when compared to the figures of first year of study period. Highest increased rate over the previous year rate $88.82 \%$ and lowest $-31.88 \%$ ( decreased) have been registered in the years 2015-16 and 2010-11.

* Nonperforming assets of Foreign banks in India billions of rupees though appearing to be decreased in the years 2010 to $2014-15$, they have been increasing at an increased rate. It has increased 2.65 times when compared to the figures of first year of study period. Highest increased rate over the previous year rate $140.26 \%$ and lowest -55.90 $\%$ (decreased) have been registered in the years 2008-09 and 2010-11.

* Nonperforming assets of Banks in various sectors in India have been increasing at an increased rate.

\section{SUGGESTIONS}

1. NPAs of scheduled commercial banks are to be reduced. During the last three years of study period, 2014 15; 2015-16 and 2016-17, they were doubled and in the last year also a higher increase was registered.

2. Among all banks of different sectors NPAs of banks in public sectors are the highest. They have increased by 26.5 times when compared to the figure of first year of study. Necessary steps are to be taken to control them otherwise it will adversely affect solvency.

3. Study period of old private sector banks is only 8 years till the financial year 2012-13.

During this period, NPAs though comparatively lower, it is necessary to control them.

4. New private sector banks also have been registering increased levels of NPAs during the study period. They have to analyse the reasons for this and go in search of further improved methods to make NPAs performing assets.

5. The NPAs of foreign banks have been showing comparatively very less growth throughout the study period. Though it is appearing to be not that much problematic
Published By: Eyes Intelligence Engineering \& Sciences Publication 
when compared to NPAs of other banks of other sectors, it is necessary to reduce them to the minimum possible extent.

6. From the side of banks, they have to take all the necessary systematic steps in examining the project proposals, feasibility, legality, ground reality and in monitoring the post sanction period. Utmost care should be taken while sanctioning the loans and advances which is not to be influenced from various outside avenues.

7. Government should also see that proper Control and Regulatory mechanism must be employed and strengthened with need based changes and reforms to ensure control over the sanction of loans and advances for the minimisation of Non-Performing Assets.

\section{CONCLUSION}

Increasing Non-Performing Assets is the indication of an insufficient and inefficient application of debt recovery management techniques. It adversely affects the growth and development of bank. On Performing assets of all banks in all sectors have been increasing at an increased rate. Regarding this Public sector banks are in the first position followed by the scheduled commercial banks .Regarding this among all banks of different sectors, old private sector banks and foreign banks are comparatively in the better position. It can be stated that these two sector banks are able to employ a better performing methods or mechanism in making the Non-Performing Assets performing better than the other banks of other sectors. It is observed that during the study period particularly during the last three financial years, NPA's of all banks of all sectors have registered very higher growth when compared to the rest of the period starting from the year 2006-07. It has happened almost all too all banks of all sectors may be its effect has been comparatively less to some banks of some sectors. But tremendous increase in NPA's to all banks can be observed during this period. All banks must go in search of clarifications regarding this and take necessary steps not to have in future.

\section{REFERENCES}

1 RBI -Handbook of statistics on Indian Economy

2 RBI - Annual reports

3 Arunkumar (2018): Banking Industry and NonPerforming Assets

4 R.K.Guptha\& Himansu Guptha (2017): Credit Appraisal and Analysis of financial Statements

5 Dr Rajkumar Mittal \& Ms Deeksha Suneja (2017) : The problem of rising NPAs in Banking sector in India

6 Vivekrajbahadur Singh (2016): A study on NPAs of Commercial banks and its recovery in India

7 Harishikes Bhattacharya (2011): Banking strategy, Credit Appraisal and lending decisions. 